\title{
The Impact of Extractive Industry on Sierra Leone Economy: (Implication for Poverty Reduction)
}

\author{
Alie Faroh \\ Department of Economics, Ernest Bai Koroma University of Science and Technology, Makeni, Sierra Leone \\ Email address: \\ farohali@yahoo.com \\ To cite this article: \\ Alie Faroh. The Impact of Extractive Industry on Sierra Leone Economy: (Implication for Poverty Reduction). Journal of Business and \\ Economic Development. Vol. 4, No. 2, 2019, pp. 64-73. doi: 10.11648/j.jbed.20190402.14
}

Received: May 16, 2019; Accepted: June 28, 2019; Published: July 19, 2019

\begin{abstract}
Extractive industry which consists of agriculture, mineral and hydrocarbon products such as gold, phosphates, diamonds, oils, gas, etc. The industry is the economic block for many developing countries; in some cases this industry constitutes the sole source of fiscal revenues, foreign exchange earnings and surpluses to finance the needed socio-economic development. This paper used different approach by taking the entire extractive industry and examining its impact on economic growth and also the link between resource revenue and poverty reduction. This study used multivariate regression techniques in econometric to analyze time series data for period of forth nine years (49) from 1964 to 2012, using quantitative and explanatory research approach, both E-view and Stata Software were used to analyzed the data, the necessary diagnostic tests associated with time series data were carried out in order to make the results reliable and valuable. Our results indicate a positive relationship between resource wealth and economic growth. The finding appears robust in the sense that it remains significant in growth model after controlling for a variable like population; we find that the effect remains the same. The exchange rate is significant, meaning that exchange rate volatility is key factor affecting the growth rate of the economy of Sierra Leone. The domestic savings is significant, and shows a positive relationship with economic growth, as many empirical literatures shows that savings and investment are good for economic growth, this finding has been proven in our case here for Sierra Leone. The population variable is significant with positive sign, meaning that population can contribute to economic growth positively, especially when the labor force is provided with adequate training and skills. Finally, we conclude by accepting the null hypothesis; that extractive resources particularly the hydrocarbon and other mines resources have a positive relationship with economic growth. Some policy recommendations are; The Government should promote and enforced mineral resources revenue stabilization and reducing fiscal imbalances, Encouraging mining companies to behave in a more social and corporate responsible manner with a view to improving the social relevance of mining. The government through the central bank and the ministry of finance should direct policy towards inflation and exchange rate volatility. The government should maintain all the principles and guidelines and strictly follow the Extractive Industry Transparency Initiative (EITI) rules.
\end{abstract}

Keywords: Extractive Industry, Economic Growth, Poverty Reduction, Policy, Sierra Leone

\section{Introduction}

Extractive industry which consists of agriculture, mineral and hydrocarbon products such as gold, phosphates, diamonds, oils, gas, etc. The industry is the economic block for many developing countries, in some cases this industry constitutes the sole source of fiscal revenues, foreign exchange earnings and surpluses to finance much needed socio-economic development. Since 2002 the price of many mined commodities has risen, which has led to the higher growth rate of many resources rich nations in some cases to record heights. The dramatic growth of China seems to be one of the most important factors explaining this boom, and as China looks certain to continue on its current economic path, it is well understood by the world that the price of mined commodities will remain high for the next future. Natural resources are relatively more prevalent among developing countries. It thus appears that the generosity of nature may sometimes - although by no means always turn out to be a mixed blessing. Take Botswana and Sierra Leone, both of which produce gen diamonds and other minerals for export. By and large, Botswana has managed the revenue and 
rent stream well from its main natural resource in such a way that has contributed to impressive economic growth since independence in 1966 in fact, with a GDP per capita of about US\$70 per year in the late 1960s_-Botswana has since transformed itself into one of the fastest-growing economies in the world, now boasting a GDP (purchasing power parity) per capita of about $\$ 16,400$ per year as of 2013 .

Meanwhile, Sierra Leone has remained mired in poverty, ravaged by crippling internal warfare which triggered the brutal civil war in early 1990 s to 2002 , continued to fight for control over the diamond trade. Sierra Leone was the world's poorest country in 1998 according to the World Bank (2000). Apparently, the rich supply of diamonds has turned out to be a source of domestic strife that has both diverted precious national resources towards rent seeking of the most destructive kind and destroyed the infrastructure and social institutions that are so important for economic life.

This example shows that the existence of natural resources can be both a blessing and a curse to economic growth and development. Recent empirical research suggests that an abundance of natural resources can hurt economic growth indirectly by unleashing forces that hamper the development of the Governance issues such as weak environmental policy, resource utilization policy and fiscal policies has come to be viewed as key factors inhibiting the ability of countries to use revenues from their extractive industries for development.

In many resource-rich countries in Africa, however, the lack of accountability and transparency in the management of these revenues exacerbates poor governance and often fuels cycles of corruption, conflict, and poverty. As the international community seeks alternatives to Middle Eastern oil and new reserves enter production, Africa's oil revenues will multiply over the coming decade.

A number of analysts believe that economies that are overly dependent on oil wealth encourage authoritarian rather than democratic forms of governance. To meet this challenge, civic groups, government reformers and representatives of the international community are increasingly pushing for more accountability and fiscal transparency in a number of sub-Saharan African countries. These reformist groups need specialized tools and knowledge to guard against increased corruption in resource-rich democratic states and to fight authoritarian regimes seeking to further consolidate their power. Effective transparency initiatives must foster cooperation beyond governments and multinational corporations to include the participation of legislative bodies, political parties, civic organizations and the media.

Others only estimated the impact of mining on the economic growth. This paper use different approach by taking the entire extractive industry and examining its impact on economic growth and also the link between resource revenue and poverty reduction.

\subsection{Objective}

The objectives of this research will be to address this following:

To assess the impact of extractive industry sector on the economic growth.

\subsection{Research Questions}

What is the role of extractive industry in economic growth?

\subsection{Hypothesis $\mathrm{H}$}

Total resource rent from hydrocarbon and mine resources jointly have positive effect on economic growth (GDP).

\section{Literature Review}

\subsection{Empirical Literature}

There is an extensive body of empirical literature on the role of mineral resources in economic development. The schools of thought are divided between those who argue that mineral resources are a curse and that, in general, growth in mineral-rich and dependent economies has been worse than in less endowed countries and scholars who consider mineral resources an endowment that has the potential to spur growth and development in developing countries.

Those who are not persuaded about the role of mining as a growth engine reason that most mining in developing countries is a capital-intensive enclave industry, foreignowned, operated largely by expatriates, and uses inputs (especially equipment) purchased abroad. In addition, they state that output, income and employment multipliers in mining, as well as its learning-by-doing potential are lower than in other sectors, particularly manufacturing. This view is reflected and typified almost in unison in studies by Auty [14], Sachs and Warner [5], Mikesell [6], and Ross [7], who argue that the richer the natural resource endowment, the greater the likelihood of decelerating economic growth. Accordingly, the boom and bust nature of mining is said to engender poor development performance and substandard welfare social indicators. They further observe that the record of oil and mineral rich states in alleviating poverty is worse than states with similar levels of income, but little or no oil and mineral wealth.

For example, Snider [8] asserts that mineral production creates rentier states, and weakens them, because they have lesser political extractive capacity to tax their constituencies. Revenues from mining production remove the need for these governments to penetrate their societies to levy and extract more taxes from the population. Consequently, in times of crisis, such countries are rendered vulnerable because they are far less capable of mobilizing the human and material resources of their societies to meet external threats. It is further said, that access to easy money (mineral wealth) lowers financial discipline, leads to reckless budgetary practices and weakens traditional work ethics, since the majority would be involved in the distribution or utilization of the mineral wealth rather than in creating other forms of wealth. Shaffer [9] notes that "the loss of flexibility to restructure the mineral economy in a volatile global economy leads to an inability to respond naturally to mineral price 
shocks. This in turn causes the state to become involved in lifesaving exercises due to the mineral sector's incapacity to manage market risks.

As Davis [10] notes, "When the entire set of mineral economies is examined, the heterogeneity and inter-temporal variability of their performances prevents any useful typification". For them, the problems associated with mineral dependence are political rather than economic and they can be linked to the capacity of governments and society to respond to large windfall revenues from mineral production. In most cases, these revenues are squandered rather than productively invested.

Stijns [11] observes that it is the primary export intensity rather than natural resources per se that has a significant negative influence on growth rates. He further indicates that natural resources affect economic growth through both positive and negative channels and that what matters most in terms of economic development is what countries do with their natural resources. He notes that those who object to the exploitation of mineral resources do not provide an alternative development route and that their arguments seem to suggest that developing countries would be better off leaving their natural resources undiscovered and/or unexploited.

Ades and Di Tella [12] use cross-country regressions to show how natural resource rents may stimulate corruption among bureaucrats and politicians. Acemoglu et al. [13] argue that higher resource rents make it easier for dictators to buy off political challengers.

In the Congo the "enormous natural resource wealth including $15 \%$ of the world's copper deposits, vast amounts of diamonds, zinc, gold, silver, oil, and many other resources gave Mobutu a constant flow of income to help sustain his power'. (p. 171) Resource abundance increases the political benefits of buying votes through inefficient redistribution. Such perverse political incentives of resource abundance are only mitigated in countries with adequate institutions. On this our approach complements recent political economy papers such as Acemoglu and Robinson, Robinson et al. [14] and Acemoglu et al. [15]. Other examples of slow growth among resource rich countries are the many cases where the government is unable to provide basic security. In such countries resource abundance stimulate violence, theft and looting, by financing rebel groups, warlord competition, Skaperdas [16], or civil wars.

\subsection{Economic Growth and Poverty}

Rapid economic growth is often essential for achieving a reduction in absolute poverty. As growth may be associated with increased income inequality, it does not automatically address the whole poverty problem. The traditional economic development literature considered highly unequal income and wealth distribution as a necessary condition for continued and rapid economic growth. The new political economy literature, on the other hand, links greater inequality to lower future growth paths, and considers it an impediment to poverty-reducing growth, as the elasticity of poverty with respect to growth is found to decline when inequality increases (e.g. Nissanke and Thorbecke). Helpman, [17], the research in this area has not, however, been able to identify the mechanisms through which this happens. One possible explanation is credit market failure, whereby the poor are unable to use growth-promoting investment opportunities (in physical and human capital). The higher the proportion of credit-constrained people, the lower the level of investment and the rate of growth are. High inequality, manifested in a large proportion of population having poor health, nutrition, and education, is also likely to impact on overall labour productivity and to cause slower economic growth, (Todaro [18]. Raising income levels of the poor, on the other hand, stimulates demand for domestic products and increases employment and production. More equitable distribution of income may also act as a material and psychological incentive to widespread public participation in the development process, (Todaro, [19], whereas inequality may cause political and economic instability.

Even if there is no consensus on the proportion of the world's population living in absolute poverty, it is highly likely that the share of the poor in the global population has declined during the last two decades (see e.g.Wade, [20]. This is largely due to rapid economic growth in countries like China and India. Differences between regions are, however, remarkable in the developing world. Especially in SubSaharan Africa, the number of poor people [living on less than $\$ 1.08$ a day (PPP)] significantly increased between 1981 and 2001, Chen and Ravallion, [21]. Inequality between countries seems to have increased (e.g. Wade, 2004). Evidence on that is, however, somewhat controversial (as examples see e.g., Sala-i-Martin, 2002, and Milanovic, 2002) and depends e.g. on the methods used, countries included, timeframe and so on. During the 1950s and 1960s there was a widespread move towards greater egalitarianism in many developing countries. Despite a decline, however, inequality remained high in many places because of the persistence of the traditional causes of inequality like high land concentration, unequal access to education and other public services, and the dominance of the mining and plantation sectors, Cornia, [22]. During the past twenty five years, inequality has been increasing again in many developing and developed countries. In Latin America, income inequality increased in many countries in the 1980s and also in the 1990s. Trend reversal also occurred in highly successful East Asian countries - where inequality decreased between the late 1950s (or early 1960s) and the late 1970s and early 1980 s - and in India and

China. Over the past 50 years, income inequality in China has followed a Ushaped pattern with the turn-around point located around the mid-1980s. Due to rapid economic growth there has, however, been a dramatic reduction industrial development and economic growth in overall poverty in the 1981-2001 period. In India, the Gini coefficient of household consumption expenditure fell in the 1950 s as a result of the partial land reform and affirmative action in favour of low caste groups, and stayed more or less at the same level until it 
rose in the 1990s during the years of gradual liberalization and globalization [23].

However, due to rapid growth India has also experienced a significant decline in poverty since the $1980 \mathrm{~s}$. As the growth experiences of Taiwan and South Korea show, rapid economic growth does not inevitably lead to increased inequality at the early stages of development. Taiwan and South Korea have been able to combine economic growth and industrialization with decreased inequality, even if inequality has somewhat increased during recent years. However, some other countries have been less successful. In Thailand, for instance, rapid growth was accompanied by increased income inequality [24].

In general, the impacts of inequality on growth and of growth on inequality depend very much on national characteristics and initial levels of poverty and inequality, but especially on the nature of the development process - how growth is achieved, who participates, which sectors are given priority. The choice is not so much between growth and equality, but about the type of economic growth to be pursued [25] and the policies to achieve.

Development strategy and economic policies may also have differential impacts on the reduction of poverty via their impact on growth. Economic strategies and policies also affect distribution by altering the way an economy generates and absorbs economic growth. Outward looking policies, for example, encourage a country to intensify its production in industries that employ abundant, and therefore low-cost, resources. If these economies are either labor-abundant or both land- and labor-abundant, these policies will enhance the impact of growth on poverty alleviation. But if the economy is mineral-rich, or if it has concentrated agriculture in the hands of a few wealthy landowners, the impact on poverty will be weak.

According to Herrick and Kindleberger [26] economic growth involves the provisions of inputs that lead to greater outputs and improvements in the quality of life of a people. Jhingan [27] refers to it as a quantitative and sustained increase in a country's per capita output or income accompanied by expansion in its labour force, consumption, capital and volume of trade and welfare (see also Thirlwall [28]).

According to Todaro [29] and the World Bank [30] to determine the growth of any country's economy certain indicators are usually taken into consideration. These indicators include: (i) the nation's (GDP); (ii) the nation's per capita income (iii) the welfare of the citizens; and (iv) the availability of social services and accessibility of the people to these services. GDP refers to the total output of final goods and services produced in a country during any given period of time by residence of a country irrespective of their nationality. Per capita income is the total national income divided by the population of a country. Welfare is usually determined by the increased and sustained flow of goods and services consumed by the people with the resultant effects of an increase in life expectancy at birth, reduction in infant and maternal mortality. Availability of and accessibility to social services include health care services, education and clean water. (see also Thirlwall 1972; Meire 1982; World Bank 2005).

According to Calamitsis, Hernandez-Cata. Ouattara [31] and Dollar and Kraay [32] the progress in the above indicators are better determined by the following factors; good rule of law, a well-defined property rights for landholders and informal entrepreneurs, openness to international trade, developed financial markets that strengthens savings mobilization and intermediation and promote sound banking systems, macroeconomic stability, moderate size of government, political stability and security of life, a capable and efficient civil service, a transparent and predictable and impartial regulatory and legal system, and good governance with emphasis in tackling corruption and inefficiency and in enhancing accountability.

As observed by Edwards [33] economic growth can reduce poverty through two channels; (i) when there is increase in employment and improvement in the opportunities for productive activities among the poor. This suggest that growth that emphasized labour-intensive strategy is generally more effective in reducing poverty than growth that is biased against export; (ii) when economic growth is associated to increase in productivity it will improve wages and under most circumstance the poor segments of the society will see an improvement in their living condition. This form of approach (economic growth approach) is evidence in most East Asian countries e.g. Japan, Hong Kong, South Korea, Malaysia, Singapore and Indonesia, which given the remarkable increase in their GDP, per capita income, welfare and improvement in the quality of their social services, inequality and poverty have reduced.

\section{Methodology}

This study used multivariate regression techniques in econometric to analyze time series data for period of forth nine years (49) from 1964 to 2012, which has been collected from various sources like, statistics of Sierra Leone, World Bank, Bank of Sierra Leone, IMF, UN Data Based, Africa Development indicator. This study is a case survey because it's focused specifically on Sierra Leone Extractive Industry. Using quantitative and explanatory research approach, both E-view and Stata Software were used to analyzed the data, the necessary diagnostic tests associated with time series data were carried out in order to make the results reliable and valuable, in which a regression table and other test tables were presented.

\section{Model Specification}

In specifying the model emphasis is placed on whether the extractive industry has any significant influence on the economic growth.

Real Gross Domestic Product (RGDP) measured in Million US Dollar, was used as a proxy for economic growth, gross domestic savings (gds) as a proxy for investment contribution to economic growth, population (pop) as a proxy for labor productivity to growth, total natural resource rent 
(tnrr) as a proxy for resource wealth contribution to economic growth and official exchange rate (exchr) as a proxy for competitiveness.

Wherein two models were regressed in order to make the result robust, by looking at both dependent variable and independent variables all in level form to determine their relations;

$$
\begin{gathered}
\mathrm{Yt}=\beta \mathrm{o}+\beta 1 \text { Gdst }+\beta 2 \text { Popt }+\beta 3 \text { Tnrrt }+\beta 4 \text { Exchrt }+\mu \mathrm{t} \\
\mathrm{Yt}=\beta \mathrm{o}+\beta 1 \text { Gdst }+\beta 2 \text { Tnrrt }+\beta 3 \text { Exchrt }+\mu \mathrm{t}
\end{gathered}
$$

Where, our dependent variable Y; is the real GDP, Tnrr; is the Total natural resource rent which comprises of the; forest rent, Oil rent, Coal rents and Mineral rent as \% of GDP, Pop; is the annual population growth rate, Gds; is the gross domestic savings as percentage of GDP, Exchr; is the official exchange rate annual. $\mu=$ is the error or disturbance term. $\beta 1$ to $\beta 4=$ the parameter estimates that stands for the speed of convergence or divergence of the independent variables.

\section{Data Analysis and Results Discussion}

\subsection{Diagnostic Tests}

\section{Test for Stationarity}

It is important to determine if the time series is stationary because time series data usually follow a particular trend and therefore the need to de-trend it otherwise spurious results will be obtained (Gujarati, 1995). Non-stationarity of time series data means that predictions based on them have little stability over time and therefore of little predictive value. If the series are non-stationary, standard econometric techniques can lead to misleading results.

Therefore, it is important to remove the non-stationarity one way of removing non stationarity is through the method of differencing. Unit Root test has been conducted to find out the stationarity of the time series. For the unit root test of time series, the method being used is the Augmented Dickey Fuller Test (ADF).

Table 1. Unit Root Test.

\begin{tabular}{lllll}
\hline VARIABLES & INTERCEPT AND TREND & ORDER OF INTEGRATION & PROBABILITY & CONDITION \\
\hline GDP & $-11.37369^{*}$ & $\mathrm{I}(1)$ & 0.0000 & Stationary \\
GDS & $-7.609712^{*}$ & $\mathrm{I}(1)$ & 0.0000 & Stationary \\
POP & $-4.421592^{*}$ & $\mathrm{I}(2)$ & 0.0010 & Stationary \\
TNRR & $-3.582555^{* *}$ & $\mathrm{I}(0)$ & 0.0098 & Stationary \\
EXCHR & $-6.642512^{*}$ & $\mathrm{I}(1)$ & 0.0000 & Stationary \\
\hline
\end{tabular}

$*, * *$ stand for level of significance at $1 \%$ and $5 \%$ respectively

The decision rule here is if and only if the "P-value from ADF test $>.05$ " then null (Ho) is accepted. Otherwise, the null hypothesis will be rejected. We apply ADF-test to economic growth, gross domestic savings, annual population level, natural resource rents and official exchange rate separately. We get all the series are non-stationary (has a unit root) at their level form except Total Natural Resource Rents (TNRR) shown stationary both in intercept and trend at 5\% level of significance, hence it important to check for cointegration, variables; growth (GDP), gross domestic savings GDP, official exchange rate and population variables became stationary after first difference and are integrated of order one I (1) at $1 \%$ level of significance. Then our test confirmed now that all the variables are stationary. Therefore that predictions based on them have greater stability over time and positive predictive values and the results are not misleading.

\subsection{Co-Integration Test}

\section{Johansen cointegration tests}

Economic theory often suggests that certain pairs of economic or financial variables should be linked by a long run economic relationship. Even if the five variables series, individually are integrated of order one I (1), it may be possible that a linear combination of the five variables may be stationary. Even if each of them individually are nonstationary (i.e. I (1)), as long as they are co-integrated, the regression involving the five series may not be spurious. Thus, we now investigate whether the six series are co- integrated and have a long run equilibrium relationship.

This process involves determining the presence of any cointegrating relationships among the variables in the model. This is particularly important to confirm or refute a long-term relationship among the variables (Johansen, 1995). This approach avoids the spurious regressions'(Granger \& Newbold, 1987) that are common when using trended data.

Table 2. Unrestricted Cointegration Rank Test (Trace).

\begin{tabular}{lllll}
\hline $\begin{array}{l}\text { Hypothesized } \\
\text { No.of CE (s) }\end{array}$ & Eigenvalue & $\begin{array}{l}\text { Trace } \\
\text { Statistics }\end{array}$ & $\begin{array}{l}\text { 0.05 Critical } \\
\text { Value }\end{array}$ & Probability \\
\hline None* & 0.614573 & 94.89005 & 69.81889 & 0.0082 \\
At most 1* & 0.377429 & 50.08014 & 49.85613 & 0.0304 \\
At most 2 & 0.274397 & 26.27227 & 29.79707 & 0.1207 \\
At most 3 & 0.176121 & 11.19692 & 15.49471 & 0.1997 \\
At most 4 & 0.043525 & 2.091534 & 3.841466 & 0.1481 \\
\hline
\end{tabular}

Trace test indicates 2 cointegrating variables at the 0.05 level.

*denotes rejection of the hypothesis at the 0.05 level.

Table 3. Unrestricted Cointegration Rank Test (Maximum Eigenvalue).

\begin{tabular}{lllll}
\hline $\begin{array}{l}\text { Hypothesized } \\
\text { No. of CE (s) }\end{array}$ & Eigenvalue & $\begin{array}{l}\text { Max-Eigen } \\
\text { Statistics }\end{array}$ & $\begin{array}{l}\text { 0.05 Critical } \\
\text { value }\end{array}$ & Probability \\
\hline None* & 0.614573 & 44.80991 & 33.87687 & 0.0017 \\
At most 1 & 0.377429 & 23.58434 & 27.58434 & 0.1416 \\
At most 2 & 0.274397 & 15.07535 & 21.13162 & 0.2837 \\
At most 3 & 0.176121 & 9.105385 & 14.26460 & 0.2775 \\
At most 4 & 0.043525 & 2.091534 & 3.841466 & 0.1481 \\
\hline
\end{tabular}

Max-eigen test indicates 1 cointegrating variables at the 0.05 level

*denotes rejection of the hypothesis at the 0.05 level.

The series for all the variables in the model used were 
tested for cointegration using the trace tests and maximum eigenvalue tests. The trace tes indicate that there are two (2) cointegrating variables, while maximum eigenvalue tests indicate that there are one (1) cointegrating variable, hence both indicates that the real GDP and the explanatory variables are cointegrated at $95 \%$ level of confidence. The variables used in this study have long run equilibrium relationship.

\subsection{Test for Functional Form Misspecification}

Ramsey RESET Test:

$\begin{array}{llll}\text { F-statistic } & 1.282433 & \text { Probability } & 0.287999 \\ \text { Log likelihood ratio } & 2.904532 & \text { Probability } & 0.234039\end{array}$

Null hypothesis: functional form is correctly specified.

This test shows that the level form of our model is correct, since the F-statistics is 1.28 , and the associated P-value is 0.288 , we do accept the null hypothesis at all significance level.

\subsection{Test for Heteroskedasticity}

$\begin{array}{lcll}\text { White Heteroskedasticity Test: } & & \\ \text { F-statistic } & 1.451648 & \text { Probability } & 0.382150 \\ \text { Obs*R-squared } & 4.059463 & \text { Probability } & 0.361719\end{array}$

Null hypothesis: homoskedasticity in the model.

The test for heteroskedasticity comfirm that the model homoskedastic, that the F-statistics $=1.45(\mathrm{P}$-value $=0.38)$ and $\mathrm{Obs}^{* \mathrm{R}}$-square=4.05 (P-value=0.36). Therefore, we fail to reject the null hypothesis of homoskedasticity in the model with the level functional form. The OLS estimator is the best linear unbiased estimator (BLUE).

Table 4. Robust Regression Output.

\begin{tabular}{|c|c|c|c|c|c|c|}
\hline \multirow[b]{2}{*}{ Independent Variables } & \multicolumn{6}{|c|}{ Dependent variable $=$ gdp } \\
\hline & Model (1) & T-Stat & probability & Model (2) & T-Stat & Probability \\
\hline Gds & $\begin{array}{l}\text { Gdp } \\
16.61 * * * \\
(5.269)\end{array}$ & 3.15 & 0.003 & $\begin{array}{l}\text { Gdp } \\
16.33^{* * * *} \\
(5.264)\end{array}$ & 3.10 & 0.003 \\
\hline Pop & $\begin{array}{l}37.77 * * \\
(36.81)\end{array}$ & 2.03 & 0.017 & & & \\
\hline Tnrr & $\begin{array}{l}30.32 * * \\
(11.94)\end{array}$ & 2.54 & 0.015 & $\begin{array}{l}25.55 * * \\
(11.01)\end{array}$ & 2.32 & 0.025 \\
\hline Exchr & $\begin{array}{l}0.280 * * * \\
(0.0391)\end{array}$ & 7.16 & 0.000 & $\begin{array}{l}0.288 * * * \\
(0.0382)\end{array}$ & 7.54 & 0.000 \\
\hline Constant & $\begin{array}{l}541.1 * * * \\
(182.7)\end{array}$ & 2.96 & 0.005 & $\begin{array}{l}659.3 * * * \\
(141.9)\end{array}$ & 4.65 & 0.000 \\
\hline Observations & 49 & & & 49 & & \\
\hline R-squared & 0.605 & & & 0.596 & & \\
\hline
\end{tabular}

Standard errors in parentheses

$* * * \mathrm{p}<0.01, * * \mathrm{p}<0.05, * \mathrm{p}<0.1$

Durbin-Watson stat: 2.27312. Prob (F-Statistic): 0.0000

A test for autocorrelation and spuriousness has been carried out using the Durbin Watson statistic and it has recorded a value of 2.27312. This shows us that there is no autocorrelation and no first order serial correlation since DW statistic is around 2. And Prob (F-statistic) 0.00000, shows that the model is correctly specified and this means that the independent variables correctly explains the dependent variable.

Two models were regressed in order to make the result robust. In model one which consists of gross domestic savings (gds), total resource rent (tnrr), population (pop) and exchange rate (exchr) variables were regressed against the real GDP as the dependent variable, $R$ squared $\left(R^{2}\right)$ of 0.605 means that $61 \%$ of the variation in growth is being explained by the independent variables in the model and there is a strong relationship between economic growth and the independent variables while the remaining $39 \%$ is being captured by the error term. However, introducing the model two, by controlling for population (pop) variable to make a robustness check for total natural resource coefficient, the Rsquare $\left(\mathrm{R}^{2}\right)$ reduces to 0.596 that is to $60 \%$ variation which is still very significant.

\section{Result and Discussion}

The exchange rate (Exchr) coefficient is statistically significant at $1 \%$ level in both models, meaning that exchange rate volatility is key factor affecting the growth rate of the economy of Sierra Leone positively. The impact of exchange rate volatility on investment and hence on economic growth is not a recent source of concern. It is noted in the literature that uncertainty reduces investment in the presence of adjustment costs and when the investment process includes irreversibility. Real exchange rate uncertainty creates an uncertain environment for investment decisions and therefore, investors delay their investment decisions to obtain more information about the real exchange rates if investments are irreversible and exerts negatively on economic performance.

Our result is in contrary to; Campa and Goldberg [35] found a negative impact of exchange rate volatility on investment. And consistent with; Aizenman [36] finds positive relationship. While Campa and Goldberg [37] find almost no impact. Recurrent booms and busts tend to increase exchange rate volatility (Gylfason, Herbertsson and 
Zoega; Herbertsson, Skuladottir and Zoega, [38], thus reducing investment in the tradable sector as well as exports and imports of goods and services (see Dixit and Pindyck, [39].

The coefficient on total natural resource rents (tnrr) is significant at 5\% level; show a positive relationship with economic growth in both models, although the coefficient estimate decreases in the second model checking for the result robustness. According to the estimates in both models for every $1 \%$-point increase in natural resource rent, the growth (GDP) would increase by 30.3 and 25.6 point or GDP would change by about (\$30.3million and $\$ 25.6$ million) point respectively. The result is in contrary to many previous researches done on resource as a curse. Our result is in consistent with; Louis-Marie Philippot [40], he used resource rents as a share of GDP to measure natural resource abundance, as we did; he found that natural resources have a positive effect on economic growth in transition countries. This result is robust when we introduce other additional variables (investment, trade, population, and schooling). Changing the measure of economic reform (price liberalization or level of privatization) does not alter results.

Earlier studies on the resource curse that take per capita GDP growth as dependent variable find a negative relationship between income growth and resource richness. Our dataset does not support the resource-curse argument when looking at the relationship between GDP growth and resource-richness. Clements and Johnson, 2003; Davis [41]; Davis and Tilton; Goodland, [42] point out that the reported negative outcomes of mineral economies are case-specific and that economic performance is mixed, heterogeneous and should not be generalized. Some contend that, for example, among African mineral economies there are fast growing economies (e.g. Botswana) and those with negative growth (e.g. Zambia).

As this result is a true reflection of the current situation in Sierra Leone due to the start of the mining boom after the civil with strong macroeconomic stability by the central bank and ministry finance in maintaining macroeconomic variables like interest rate, inflation and exchange rate etc, the economy has experience rapid growth. In 2012 it was ranked as the second fastest growing economy in the world behind Mongolia (according to IMF and World Bank).

The coefficient on domestic savings (gds) is statistically significant at $1 \%$ level, and showing a positive relationship with economic growth, as many empirical literatures shows that savings and investment are good for economic growth, this finding has been proven in our case here for Sierra Leone. This result indicates that, for every 1\%-point increase in domestic savings, the economy growth would increase at about 16.6 point and 16.3 point or GDP would change by about (\$16.6million and \$16.3million) in the preceding year respectively. McKinnon [43] argues that, when all economic units are confined to self-finance, money balance has to be accumulated before costly and indivisible investment projects can be undertaken, and so money and physical capital are complements. Thus, a rise in interest rate levels stimulates domestic savings and facilitates the process of accumulation and self-finance, which will have a favorable impact on investments and lead to a higher growth rate. This argument seems to be applicable to Sierra Leone. Sierra Leone nonstate enterprises and households have actually extremely limited access to bank loans. They rely largely on their own accumulation of funds for financing their investments. So their demand for money and their investments may be positively.

Our result here is in consistent with; Osekhebhen Eigbiremolen [44] who found that domestic savings significantly contribute to the variability of real GDP, and Thorvaldur Gylfason and Gylfi Zoega [45], found a positive relationship between gross savings and economic growth.

The coefficient on population (pop) variable is significant at $5 \%$ level, with the expected sign positive, meaning that any $1 \%$ increase in population growth, economic growth would increase by 37.8 point or GDP would change by about (\$37.8 million) positively, especially when the labor force is provided with adequate training and skills.

\section{Conclusion}

This paper examines the dynamic relationship between extractive resources and economic growth in Sierra Leone, with a time series data over 49 years that is, for a period of 1964 to 2012. While the literature shows mixed outcomes of resource wealth on GDP growth in developing countries, our results indicate a positive relationship between resource wealth and economic growth. The finding appears robust in the sense that it remains significant in growth model after controlling for a variable like population; we find that the effect remains the same. The exchange rate is significant, meaning that exchange rate volatility is key factor affecting the growth rate of the economy of Sierra Leone. The impact of exchange rate volatility on investment and hence on economic growth is not a recent source of concern. It is noted in the literature that uncertainty reduces investment in the presence of adjustment costs and when the investment process includes irreversibility. Real exchange rate uncertainty creates an uncertain environment for investment decisions and therefore, investors delay their investment decisions to obtain more information about the real exchange rates if investments are irreversible and exerts negatively on economic performance.

The domestic savings is significant, and shows a positive relationship with economic growth, as many empirical literatures shows that savings and investment are good for economic growth, this finding has been proven in our case here for Sierra Leone. The population variable is significant, with the expected sign positive, meaning that population can contribute to economic growth positively, especially when the labor force is provided with adequate training and skills. Finally, we conclude by accepting the null hypothesis; that extractive resources particularly the hydrocarbon and other mines resources have a positive relationship with economic growth. 


\subsection{Implication for Poverty Reduction}

1. Economic growth can contribute to poverty reduction by making accessible education and specific training at secondary-school and university level.

2. Development of domestic savings, through the increase in wage/ salaries of the poor would be good for higher consumption and reduce the food poverty.

3. Social policies to tackle specific case-related issues, such as financial help to those hit by AIDS and their families from the resource wealth.

4. Develop long-term skills and build domestic human capital, stimulate industrialization and reduce the enclave nature of mining. Diversify the economy and increase employment rates. Empower citizens and provide assistance to victims of disease or war, provide infrastructure that can benefit the poor.

5. Extractive revenue can benefit poor by government supporting the articulation of a national framework that guides decisions on spending, savings and investments of rents from extractive sectors. Develop capacity to collect taxes and support the formulation of progressive, equitable tax regimes. Work with international financial institutions and other economic institutions on advising governments in their formulation of macroeconomic and pro-poor policies. Support regional cooperation for the establishment of contractual and taxation standards. Put in place corruption risk mitigation systems (against capital flights and misappropriation of funds), for both government and companies. Develop civil society and government capacities to advocate for and ensure transparency in revenue management. Engage with initiatives such as EITI, Revenue Watch, to advocate for company commitments to transparency (EITI principles). Develop local capacities in responsive and accountable governance by strengthening state-citizen interactions, gender-sensitive and participatory planning and other social accountability initiatives to ensure sustainable management of extractive industries.

\subsection{Policy Recommendations}

i. The government should create a conducive, stable and predictable policy, and regulatory framework that can bring competitiveness with a view of attracting and retaining the required level of investment in the sector, creating wealth, promoting employment and openingup opportunities.

ii. The Government should promote and enforced mineral resources revenue stabilization and reducing fiscal imbalances, increased capacity for forecasting and managing mineral revenues well and minimizing adverse macro-economic impacts associated with commodity price fluctuations.

iii. To empower the citizens especially the labor force in mining regions to be able to make informed decisions and to better participate in their own development.

iv. Government should develop a strategy that would encourage local procurement and outsourcing of goods and services, value-addition and local beneficiation of minerals, diversification from minerals, as well as optimizes business multipliers and enhances linkages between mining and other sectors of the economy, including at local community level.

v. The government through the central bank and the ministry of finance should direct policy towards inflation and exchange rate volatility.

vi. To support the energy sector to achieve sustainable power supply in the main industrial area, as this would attract investors to invest in the country.

vii. The government should force the mining companies to build some facilities that will enhance value addition in the mineral, in order to expand country benefits from it natural resources.

viii.Achieving better mineral resources revenue allocation and redistributing the benefits of mineral wealth through improvements in the governance and management of revenue flows, the government should encourage decentralization and the involvement of local communities, stakeholders in decision-making and resource allocation.

ix. The government should maintain all the principles and guidelines and strictly follow the Extractive Industry Transparency Initiative (EITI) rules.

x. In order for the country to maintain growth, the government should enforce diversification by encouraging other sectors of the economic to grow, as it has been pointed out by many scholars that the over dependence on natural resources export by resource rich countries has led to the poor economic performance without diversification.

xi. Another key priority of the government is to fight corruption, strengthen good governance and sound macroeconomic management.

\section{References}

[1] Auty, Richard M. (ed.) (2001a), Resource Abundance and Economic Development, Oxford University Press, Oxford and New York.

[2] Auty, Richard M. (2001b), "The Political Economy of Resource-Driven Growth," European Economic Review 45, May, 839-846.

[3] Andersen, J. R. J. and Aslaksen, S. (2008). Constitutions and the Resource Curse. Journal of Development Economics, 87 (2), 227-246.

[4] Acemoglu, D, Johnson, S and Robinson, J 2003. An African success story: Botswana. In D Rodrik (ed), In search of prosperity: Analytical narratives on economic growth. Princeton: Princeton University Press.

[5] Ahammad, Helal and Clements, Kenneth (1999), What Does Minerals Growth Mean to Western Australia? Resources Policy, Vol. 25, pp. 1-14. 
[6] Bardhan, Pranab (1997), "Corruption and Development: A Review of the Issues," Journal of Economic Literature 35, September, 1320-1346.

[7] Basedau, Matthias, and Andreas Mehler (2003): African Resources and War, in: Internationale Politik, 4, 3, 95100.

[8] Basedau, Matthias, and Jann Lay (2009): Resource Curse or Rentier Peace? The Ambiguous Effects of Oil Wealth and Oil Dependence on Violent Conflict, in: Journal of Peace Research, 46, 6, 757-776.

[9] Basedau. M (2005): Context Matters Rethinking the Resource Curse in Sub-Saharan Africca online: retrived $15^{\text {th }}$ November, 2014:

http://www.gigahamburg.de/dl/download.php?d=/content/publ ikationen/pdf/wp 01-basedau.pdf

[10] Basedau. M, and Wolfram L (2009): A Paradox of Plenty? Rent Distribution and Political Stability in Oil States, online: $18^{\text {th }}$ November, 2014:

http://www.gigahamburg.de/dl/download.php?d=/content/publ ikationen/pdf/wp21basedaulacher.pdf.

[11] Collier, P. and Hoeffler A. (2002), Greed and Grievance in Civil War, Centre for the Study of African Economies

[12] Collier, P. and Hoeffler A. (2005) Resource Rents, Governance, and Conflict, Journal of Conflict Resolution, Vol. 49, (4) 625-633.

[13] Collier, P. and Hoeffler, A. (1998) 'On Economic Causes of Civil War’, Oxford Economic Papers, 50, 563-73.

[14] Corden, W. Max (1984), "Booming Sector and Dutch Disease Economics: Survey and Consolidation," Oxford Economic Papers 36, 359-380.

[15] Chen, S. and Ravallion, M. (2004), How have the world's poorest fared since the early 1980s, World Bank, processed.

[16] Cornia, G. A. (2005), Policy reform and income distribution. Paper presented in the DESA development forum: Integrating economic and social policies to achieve the UN development agenda. New York, 14-15 March 2005.

[17] Cornia, G. A. and Kiiski, S. (2001), Trends in income distribution in the post- World War II period. Evidence and interpretation. Discussion paper no. 2001/89, United Nations University, World Institute for Development Economics Research.

[18] Calamitsis, E. A. (1999) Adjustment and Growth in SubSaharan Africa: The Unfinished Agenda. IMF Finance and Development. Vol. 36 No. 1: 6-9.

[19] Dollar, D \& Kraay, A (2001) Trade, Growth and Poverty. World Bank Policy Research Working Paper No. 2615.

[20] Davis, Graham and Tilton, John E. (2002), Should Developing Countries Renounce Mining? A Perspective on the Debate, Colorado School of Mines, Denver, Colorado.

[21] Davis, G. A and Tillon J. E. (2005) The resource curse, Natural Resources Forum, Vol. 29, pages 233-242.

[22] Dollar D, Kraay A (2002) Growth is good for the poor. Journal of Economic Growth 7:195-225.

[23] Davis, G. A. (1995) 'Learning to Love the Dutch Disease: Evidence from Mineral Economies.
[24] Dixit, Avinash K., and Robert S. Pindyck (1994), Investment under Uncertainty, Princeton University Press, Princeton, N. J.

[25] Dollar, D. and Kraay, A. (2004), Trade, growth, and poverty. The Economic Journal, 114: F22-F49.

[26] Frankel, Jeffrey A., and David Romer (1999), "Does Trade Cause Growth?," American Economic Review 89, June, 379399.

[27] Gylfason, Thorvaldur (1999), "Exports, Inflation, and Growth," World Development 27, June, 1031-1057.

[28] Gujarati DN (1995). Basic Econometrics. Third edition, McGraw-Hill, Inc.

[29] Gylfason, Thorvaldur (2001), "Natural Resources, Education, and Economic Development," European Economic Review 45, May, 847-859.

[30] Gylfason, Thorvaldur, and Tryggvi Thor Herbertsson (2001), "Does Inflation Matter for Growth?," Japan and the World Economy, forthcoming.

[31] Gylfason, Thorvaldur, Tryggvi Thor Herbertsson and Gylfi Zoega (1999), "A Mixed Blessing: Natural Resources and Economic Growth," Macroeconomic Dynamics 3, June, 204225 .

[32] Government of Sierra Leone: http://www.sierraleone.org/government.html

[33] Human Development Indicator (HDI): http://hdr.undp.org/en/statistics/hdi/

[34] Herrick, B \& Kindleberger, C. P (1983) Economics Development Singapore: Mc Graw-Hill.

[35] Herbertsson, Tryggvi Thor, Marta G. Skuladottir and Gylfi Zoega (1999), "Three Symptoms and a Cure: A Contribution to the Economics of the Dutch Disease," Working Paper No. W99:10, Institute of Economic Studies, University of Iceland.

[36] Helpman, E. (2004), The mystery of economic growth. The Belknap Press of Harvard University Press, 223 p.

[37] Hernandez-Cata, E (1999) Sub-Saharan Africa: Economic Policy and Outlook for Growth. IMF Finance and Development. Vol. 36 No.1: 10-13.

[38] IMF 2007 - WP/07/213. Inter-sectoral linkages and local content in extractive industries and beyond - The case of Sao Tome and Principe.

[39] Jhingan, M. L (1985) The Economic of Development and Planning. Delhi: Vikas Publishing House.

[40] Johansen S (1995). Likelihood-Based Inference in Cointegrated Vector Autoregressive Models. Oxford University Press, New York.

[41] Kaldor, Nicolas (1966), Causes of the Slow Rate of Growth in the United Kingdom, Cambridge University Press, Cambridge, England.

[42] Knight, Malcolm, Norman. L and Delano. V, (1996), "The Peace Dividend: Military Spending and Economic Growth, IMF Staff Papers 43, March, 1-37.

[43] Lane, Phillip and Tornell, Aaron (1995), Power Concentration and Growth, Harvard Institute of Economic Research Discussion Paper, No. 1720. 
[44] Murphy, Kevin M., Andrei Shleifer and Robert W. Vishny (1993), "Why Is Rent- Seeking so Costly to Growth?," American Economic Review 83, May, 409-414.

[45] Mehlum, H., Moene, K. and Torvik, R. (2006). Cursed by Resources or Institutions? The World Economy, 29 (8), 11171131.
[46] Matsen, E. and Torvik, R. (2003), "Optimal Dutch Disease", Working Paper Series No. 1/2003, Department of Economics, Norwegian University of Science and Technology, Trondheim, Norway. 